\title{
Resenha do livro: BARBOSA, Marialva. História da Comunicação no Brasil. Petrópolis, RJ: Vozes, 2013
}

\section{Márcio Souza Gonçalves}

Doutor em Comunicação pela UFRJ, Pós-Doutor em Comunicação pelo GRIS-UFMG.

Bolsista Prociência UERJ/FAPERJ e professor da Faculdade de Comunicação da UERJ. Coordenador do grupo de pesquisa Livros e Cultura Letrada da UERJ

msg@uerj.br

\section{Yuri Garcia}

Doutorando em Comunicação Social na UERJ.

Membro do grupo de pesquisa Livros e Cultura Letrada da UERJ.

yurigpk@hotmail.com

\section{Thayz Guimarães Gonçalves}

Graduada em Jornalismo pela UERJ.

Membro do grupo de pesquisa Livros e Cultura Letrada da UERJ.I

guimaraes.thayz@gmail.com 
O livro de Marialva Barbosa História da Comunicação no Brasil tem uma importância e escopo que tornam difícil o trabalho do resenhador, o pouco espaço de uma resenha sendo largamente insuficiente para apresentar, mesmo que brevemente, a relevância e conteúdo da obra resenhada. Nada mais será feito aqui do que indicar alguns poucos pontos essenciais.

O principal deles se torna patente no próprio título, História da Comunicação no Brasil. O no Brasil aponta para a realização de uma história propriamente brasileira, que não se configura como uma aplicação, a uma suposta realidade nacional, de esquemas interpretativos fornecidos por teorias europeias e norte americanas. Tais esquemas, gerados para dar conta de realidades nacionais ou continentais bem distintas da do Brasil, terminam por funcionar como camisas-de-força que, no limite, violentam a realidade empírica em favor de uma ideal clareza teórica, evitando portanto o embate com as complexidades, contradiçóes e misturas que marcam a realidade nacional de nosso país.

Marialva Barbosa não foge à consideração dessa realidade e de sua complexidade, montando, em uma obra de síntese, um quadro rico e nuançado da comunicação brasileira em sua história. Trata-se, portanto, de obra essencial para boa compreensão da realidade comunicacional do Brasil em suas diversas facetas, que mais não podemos fazer aqui do que rapidamente esboçar.

O Brasil sempre foi, segundo a autora, uma sociedade oralizada - o burburinho das cidades é figura presente e muito importante ao longo de toda a obra. No período colonial, leituras públicas e fofocas, conversas pelas ruas, alimentavam esse som constante da cidade. $\mathrm{O}$ universo dos escravos, oral, mas atravessado pelas letras de modos em geral indiretos, mas por vezes diretos, dado que havia escravos letrados, comportava rituais que envolviam música, dança e rimas. Com a chegada da Família Real ao Brasil, de diversos estrangeiros, que aumentavam o comércio, e de prelos que foram aos poucos e timidamente se disseminando pelas províncias, a escrita passa a fazer parte da realidade do povo, mas envolvida em um mundo marcadamente oral. O letramento tropical é assim atravessado pela fala, traço sumamente importante no caso brasileiro.

O final do século XIX é marcado pela multiplicidade de públicos nas cidades, pela crescente alfabetização e por uma maior presença (ainda que bastante relativa) da cultura letrada em solo nacional. Nota-se ainda uma expansão, mesmo que incipiente, do uso de imagens em revistas e jornais, graças, principalmente, a tecnologias como a litografia e a fotografia.

Paralelamente a isto, o telégrafo surge como importante tecnologia da comunicação que possibilita uma aceleração brutal na circulação de informaçôes, engendrando, aos poucos e lentamente, um sistema de redes interligadas.

No começo do século XX, num lento processo de industrialização, o Brasil começa a se modernizar: os jornais sofrem grandes mudanças em sua formatação, de maneira a alcançar públicos e tiragens cada vez maiores, e tem início o movimento coletivo de interiorização dos meios de comunicação, que 
passam ao status de "utensílios domésticos": o rádio penetra aos poucos no espaço do lar, se tornando parte importante da dinâmica cotidiana. A Era de Ouro do rádio seria responsável por instaurar uma linguagem toda própria deste meio de comunicação, através de suas novelas, relatos jornalísticos e de seus célebres cantores e cantoras, ícones do imaginário popular.

A segunda metade do século XX assiste aos aparelhos televisores se tornarem mais comuns nos lares brasileiros, com preços mais acessíveis. Vistos como algo quase mágico, eram vinculados às ideias de comodidade e coletividade, e apontados como capazes de trazer eventos públicos (jogos de futebol e carnaval) e experiências mais particulares (filmes e possibilidades de conhecer o mundo através da tela) para dentro do conforto de casa. A televisão ocupava, claro, lugar de destaque na sala de visitas.

A TV Globo surge após o golpe militar e se consolida na década de 1970 como a maior emissora do país. Os telejornais e as novelas ganham força como as principais atraçóes para o povo brasileiro.

Com a virada do século XX para o XXI, e o boom das tecnologias digitais, o universo comunicativo se complexifica e a televisão passa a conviver com concorrentes fortes, num processo em que hibridizaçóes, misturas e convergência parecem ser a regra.

Essa história complexa, que, como dito, o espaço de uma resenha não permite apresentar corretamente, é a de uma mistura constante de meios (orais, manuscritos, impressos, eletrônicos), cuja dosagem, de maneira inovadora, a obra de Marialva Barbosa procura realizar. História da Comunicação no Brasil é relato atento dessas misturas, relato essencial para os interessados tanto no campo da Comunicação, quanto no da História do Brasil ou em ambos. 